\title{
Risk Factors for Cervical Cancer and Papanicolaou Test in Marginalized Adolescents in Bogotá, Colombia
}

\author{
Factores de riesgo para cáncer de cuello uterino \\ y resultados de prueba de Papanicolaou en \\ adolescentes marginadas de Bogotá, Colombia
}

Fatores de risco para câncer de colo uterino e prova de Papanicolau em adolescentes marginadas. Bogotá, Colômbia

María Inés Sarmiento Medina, MD. Esp. MSC¹

Miryam Puerto de Amaya, LB. TE-CH${ }^{1}$

Received: July 8, 2019 - Accepted: October 28, 2019

Doi: https://doi.org/10.12804/revistas.urosario.edu.co/revsalud/a.8746

To quote this article: Sarmiento Medina, M. I., \& Puerto de Amaya, M. (20XX). Risk Factors for Cervical Cancer and Papanicolaou Test in Marginalized Adolescents in Bogotá, Colombia. Rev Cienc Salud. 2020;18(1):37-51. https://doi.org/10.12804/revistas.urosario.edu.co/ revsalud/a.8746

\section{Abstract}

Introduction: Cervical cancer is rare in young women, so screening in women under 21 years is not recommended. However, early and intense exposure to risk factors could increase the likelihood of early pre-neoplastic lesions. Currently, particular social conditions in adolescents can favor exposure, generate changes in lifestyles, and affect their immediate and future health. This work describes the frequency of risk factors and Pap results in adolescents of a child protection center. Materials and Methods: This paper presents a retrospective cross-sectional study that measured the frequency of exposure to risk factors for cervical cancer and Pap results of 889 adolescents exposed to critical social conditions. It used information from the cytology report files made between 2011 and 2016. Results: Normal Pap smear was found in $85 \%$ of the cases. The risk factors had a very high prevalence, especially the early age of onset of sexual relations with $75 \%$ before age 14 , the number of sexual partners with more than one in $66.7 \%$, no use of a condom $95 \%$ and high cigarette consumption. Discussion: The frequency of pre-malignant cervical lesions was very low; however, in women under 21 years old with premature and intense exposure to risk factors, an early-onset conservative screening accompanied by gynecological consultation for prevention, diagnosis, or treatment can be considered. The marginalized adolescent's social problem requires interdisciplinary and intersectoral management.

Keywords: Adolescents; cytology; screening; cervical cancer; social medicine.

1 Fundación Universitaria de Ciencias de la Salud, Bogotá, Colombia.

Corresponding author: misarmiento@fucsalud.edu.co 


\section{Resumen}

Introducción: el cáncer de cuello uterino es poco frecuente en mujeres jóvenes, por lo cual no se recomienda el tamizaje en menores de 21 años. Sin embargo, la exposición temprana e intensa a factores de riesgo podría aumentar la probabilidad de aparición de lesiones preneoplásicas tempranas. Ciertas condiciones sociales en las adolescentes pueden favorecer dicha exposición, generar cambios en los estilos de vida y afectar su salud inmediata y futura. Este trabajo describe la frecuencia de los factores de riesgo y los resultados de Papanicolaou en adolescentes de un centro de protección de menores. Materiales y métodos: estudio retrospectivo de corte transversal que midió la frecuencia de exposición a factores de riesgo para el cáncer de cuello uterino y los resultados de Papanicolaou de 889 adolescentes marginadas. Utilizó información de los archivos de reporte de citologías realizadas entre 2011 y 2016. Resultados: se encontró Papanicolaou normal en el 85\% de los casos. Los factores de riesgo tuvieron una muy alta prevalencia, especialmente la edad temprana de inicio de relaciones sexuale,s con el $75 \%$ antes de los 14 años, más de un compañero sexual (66.7\%), no uso de preservativo $95 \%$ y alto consumo de cigarrillo. Discusión: la frecuencia de lesiones cervicales premalignas fue muy baja; sin embargo, en mujeres menores de 21 años con exposición prematura e intensa a factores de riesgo, podría considerarse un tamizaje conservador de inicio temprano, acompañado de consulta ginecológica para prevención, diagnóstico o tratamiento. El problema social de las adolescentes marginadas requiere un manejo interdisciplinario e intersectorial.

Palabras clave: adolescentes; citología; tamizaje; cáncer de cuello uterino; medicina social.

\section{Resumo}

Introdução: o câncer de colo uterino é pouco frequente em mulheres jovens, pelo qual não se recomenda o rastreio em menores de 21 anos. No entanto, exposição precoce e intensa a fatores de risco poderia aumentar a probabilidade de aparição de lesões pré-neoplásicas precoces. Atualmente condições sociais particulares nas adolescentes podem favorecer a exposição, gerar mudanças nos estilos de vida e afetar sua saúde imediata e futura. Este trabalho descreve a frequência de fatores de risco e resultados de Papanicolau em adolescentes de um centro de proteção de menores. Materiais e métodos: estudo retrospectivo de corte transversal que mediu a frequência de exposição a fatores de risco para o cancro de colo uterino e os resultados de Papanicolau de 889 adolescentes marginadas. Utilizou informação dos ficheiros de reporte de citologias realizadas entre 2011 e 2016. Resultados: se encontrou Papanicolau normal em $85 \%$ dos casos. Os fatores de risco tiveram uma prevalência muito alta, especialmente em idade temporã de início de relações sexuais com um $75 \%$ antes dos 14 anos, mais de um parceiros sexual no $66.7 \%$, não uso de preservativo $95 \%$ e alto consumo de cigarro. Discussão: a frequência de lesões cervicais pré-malignas foi muito baixa, no entanto, em mulheres menores de 21 anos com exposição precoce e intensa a fatores de risco, se poderia considerar um rastreio conservador de início temporão acompanhado de consulta ginecológica para prevenção, diagnóstico ou tratamento. O problema social das adolescentes marginadas requere uma gestão interdisciplinar e intersetorial.

Palavras-chave: adolescentes; citologia; triagem; câncer de colo uterino; medicina social.

\section{Introduction}

ervical cancer is the fourth cause of cancer deaths in women worldwide (1). The incidence
trend has been downwards, particularly in the developed countries, with rates lower than 6.5 per 100,000 inhabitants (2). However, it remains a concern in countries in Africa living 
in poverty; as well as in some other countries in Latin America and the Caribbean such as Peru, Bolivia, Paraguay and Haiti, with incidence rates higher than 30/100,000 (3). Mortality rates are threefold higher in Latin America than in the United States and Canada (4).

Colombia is in the group of countries with mean incidence rates, between 13.6 and 20.6/100,000, with downward trend, since in 1980 it showed rates greater than 35/100,000 (2), which could be explained by better living conditions and increased coverage of better quality health services. The goal of reducing mortality by 6.8/100,000 for the year 2015 was already met in 2013, and it continues to decrease, thus placing the country bellow the average in South America, that lies by 7.1 per 100,000 (2, 5). It is reported that cc in young women is very rare (6), however, it should be underlined that in the United States $21 \%$ of the new cases per year appear in women younger than 29 years (6). In Colombia, deaths due to cc and other uterine tumors are detected already in early ages; according to the mortality statistics presented by the National Statistics Department (DANE) in the last ten years 404 deaths in women aged between 15 and 29 years due to these two causes were reported, with rates ranging from $0.1 / 100,000$ inhabitants in the group of 15 to 19 years old; up to 3.66/100,000 inhabitants in the group between 24 and 29 years old (7).

Risk factors are fully known. The human papillomavirus infection (HPv) is considered a necessary though not sufficient condition (8-11). Other risk factors are described such as precarious socioeconomic conditions, use of tobacco, initiation of sexual activity at an early age, having more than one sexual partner, sexual activity without using a barrier method, and early age at the first pregnancy $(11,12)$.

In young women, the risk of contracting HPV is associated with an inadequate adaptive immune response, and, additionally, with physiological immaturity of the epithelium of the uterine cervix, since it is in much greater columnar type in transformation to squamous metaplasia, presenting an extensive ectopic area that, due to its fragility, can bleed, thus providing an entrance gate for the virus (13). Men play a very relevant role in the HPV due to their sexual behavior for they act as virus carriers, a particularly significant issue in countries whose male population customarily have multiple sex partners $(14,16)$.

The first pregnancy at an early age (younger than 17 years) increases the risk of developing high-risk intraepithelial lesions or cc, even more when the patient is infected with highrisk HPV (17). It is believed that hormone changes due to pregnancy could intervene in the immune response against HPV, thus causing persistence or progression of the infection (12).

The use of tobacco has been associated with the risk of contracting cc, since in recurrent smokers the probability of this risk increases, even to double $(18,19)$. Nicotine and carcinogens characteristic of tobacco have been found in the cervical mucus of smoking patients, supporting the hypothesis of a combined action of tobacco and HPV in progression and persistence of precancerous lesions, increasing the risk still further when the exposure to both agents occurs at early ages (20). It has been proved that the chemicals of tobacco act as carcinogens, 
producing a mitogenic effect that can later cause cell DNA damage and lead to Langerhans cell reduction and the decrease of immunomarkers in the cervical epithelium. This favors the loss of the capability of generating effective cellular immunity against HPV (21-23).

A correlation between cc and the presence of HPV with co-infections due to other agents in the vaginal tract, such as Herpes simplex type 2 and the Chlamydia trachomatis bacteria, has also been described (24). A relevant role of the latter in the development of cc is suggested, since it erodes the mucosa of the uterine cervix favoring the entrance of HPV and producing chronic inflammation that can interfere in the persistence of viral infection (25). In this sense, on the basis of results of a meta-analysis, Zhu et al. (2016) conclude that women with Chlamydia trachomatis infection have a higher cervix cancer risk (26).

As to the protecting factors, the Centers for Disease Control in the us (CDC) sustain that the use of barrier methods, such as condoms, when properly and constantly used, can prevent infections with some germs causing sexually transmitted diseases such as human immunodeficiency virus, Neisseria gonorrhoeae, Chlamydia tracomatis, and Trichomona vaginalis; however, their efficiency in preventing HPV and Treponema pallidum is lower because condoms do not cover all skin areas that could be infected or exposed to contagion with these pathogen agents (27). The protector factors also include vaccination for preventing infection with HPV of high oncogenic risk (28). Another factor that is being studied as possible protector is male circumcision. A systematic review of published studies performed by Grund et al. concluded that there is highly consistent evidence of an association of circumcision of the male partner with the protection of their partners against cervix cancer and cervical dysplasias (29).

cc screening through cytology has been able to reduce mortality by half in developed countries where human resources and good coverage are available guaranteeing quality, for instance in Great Britain where a reduction of $70 \%$ of deaths due to cc is attributed to its effects (30). In the last decades, DNA of HPV detection for the initial screening has been promoted since it has greater sensitivity and specificity; and cytology is being postponed for patients with HPV-positive result. When cytology is used as initial screening test, an additional HPV test is recommended for patients with low risk (LSIL) or undetermined intraepithelial lesion $(31,32)$.

Age of initiation of screening varies from one country to another. In Canada it is 24 years of age (33); in Sweden, New Zeeland and Chile, 25 years (34, 35); in Spain, between 25 and 30 years (36); in the United States it was recently reduced from 25 to 21 years old (37); in the European Union it lies between 25 and 30 years (38); and in Colombia it changed in 2018 from 30 to 25 years (31). The reasons for not performing a cytology in women younger than 21 years include lack of resources or competent staff, financial costs, unjustified emotional costs, cervix lesions due to the administered treatments, presence of false positive measurements, overdiagnosis, overtreatment $(6,39)$; additionally, it is considered unnecessary since most LSIL lesions remit spontaneously in young women in approximately a two-year period (40, 
41). However, screening for cc is still performed in adolescents in some countries, regardless of the recommendations of the guidelines $(42,43)$.

This study aims at describing the frequency of the exposure to cc risk factors and the results of the Pap test in a particular group of adolescent women experiencing critical, socially caused conditions which make them particularly vulnerable to be at risk and/or under damage both physically and psychologically. These conditions include school unattendance; break up of family relations; lack of stable housing; vagrancy in the streets; participation in drug micro-trafficking networks; use of illegal psychoactive substances, alcohol and/or tobacco; participating in criminal networks; human trafficking for sexual exploitation; and child prostitution networks. It should be noted that these conditions have been verified by child protection agencies which in fact have promoted that adolescents come under their care while a reintegration into society and their families is achieved.

The agency for child protection where these young females live is attached to the Instituto Colombiano de Bienestar Familiar, cytology is included in their routine admission clinical tests. Since this information was on file, it was considered important to analyze them collectively, for there are no studies published in literature describing the results of cytology screening in adolescents prolongedly and intensely exposed to risk factors.

\section{Materials and Methods}

$\mathrm{T}$

This research is framed in a cross-sectional retrospective study based on information of all cytology reports performed in females aged between 11 and 18 years who were examined in the period between January 2011 to June 2016, coming from one of the institutions for adolescent social service in the north of the city of Bogotá, Colombia. The cytology report format included identification data; demographic and gyneco-obstetric information, as well as information on risk factor exposure of the patients, beside the cytology results according to the Bethesda classification.

Samples for the smear were collected by two cytohistologists with more than ten years of experience at a level IV university hospital; these were processed in the pathology lab of this hospital by Pap stain and read according the Bethesda classification criteria. All positive and $10 \%$ of negative cases were reviewed and confirmed by pathologists of the pathology lab.

At the time, all samples were taken with the individual consent of the young women having previously been informed about the procedure, as well as with the consent of their legal representative, in this case, the child protection institution. To the females having not become sexually active who accepted the test, the smear was performed with cotton swab, without using speculum. Results were delivered through the direction of the institution since it is their legal representative while they are under protection. Women with high level squa- 
mous intraepithelial lesion and those who presented pathogenic vaginal flora were referred to gynecological care to continue studying the cases or to receive treatment.

Confidentiality was protected by excluding personal identification in the tabulation process and in the analysis. This work was performed in compliance with the ethical guidelines of the Declaration of Helsinki (2013) and the Resolution 8430 of 1993 of the Colombian Ministry of Health. According to the latter, this research was classified as without risk since it was a collection of anonymous documentary information. It was approved by the Human Research Ethics Committee of the San Jose Hospital in Bogotá, Record number 20 of October 26, 2016.

The findings were entered in Excel (Microsoft) version 2016, and were tabulated and analyzed with the Epi Info 3.5.1 program. Distributions of absolute and relative frequencies were used, measures of central tendency and dispersion were calculated.

\section{Results}

mong the obtained results, 891 reports were established in the research period. Average Lage of the young females was 15.24 years (sd: 1.33), in a range between 11 to 18 years. Initiation of sexual relations was between 5 and 17 years of age; 75 percentile corresponds to 14 years of age, and 25 percentile to 12 years (mean = 13, interquartile range $=2$ ) (figure 1 ); 126 adolescents (14.1\%) expressed never having had sexual relations. The number of sexual partners varied between 0 and 120. The highest frequency laid in the interval between 2 and 5 (figure 2).

Figure 1. Sexual debut age

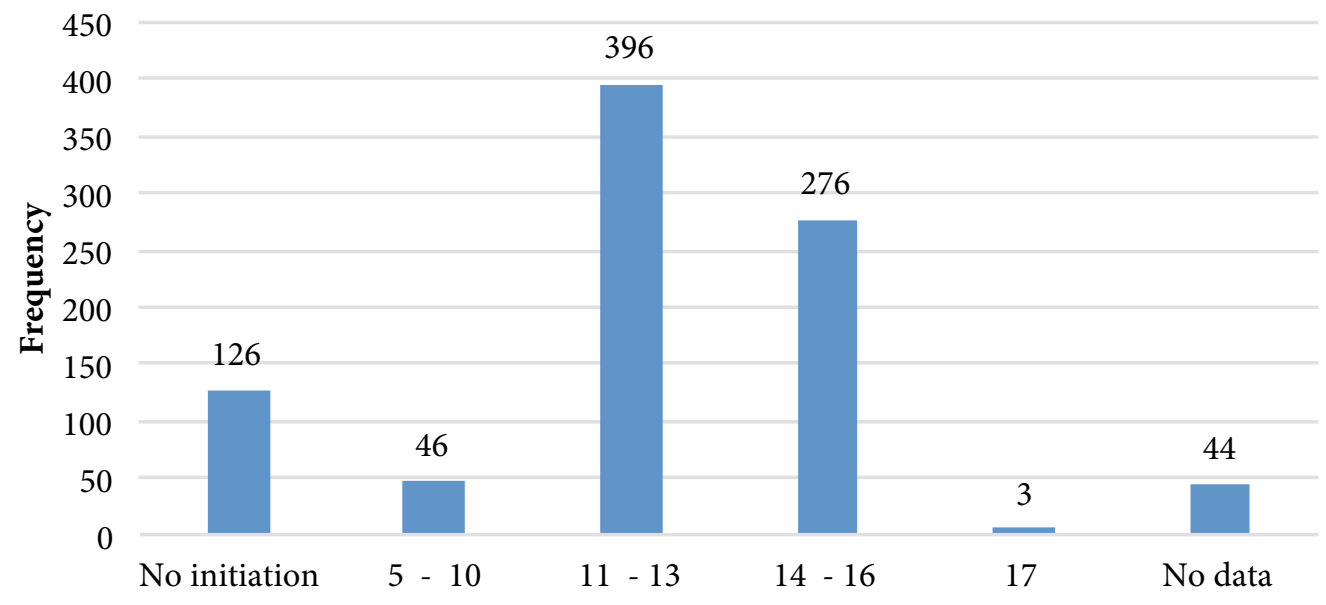


Figure 2. Number of sexual partners

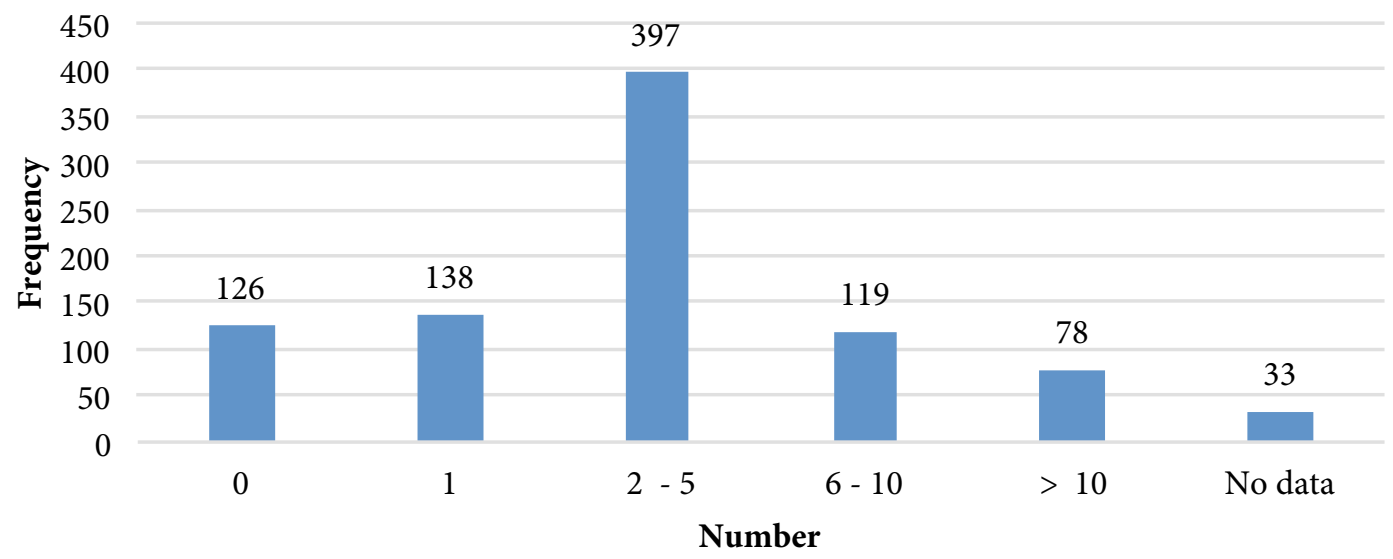

It is worth to mention that the contraceptive methods used were various; $75 \%$ of the studied population declared that they used no contraceptive methods. Condoms were used by only $4.9 \%$ of the females and $14.6 \%(n=121)$ declared having had at least one pregnancy. Considering the use of tobacco, $76.7 \%(n=659)$ habitually used tobacco before entering the child care institution, and, according to the caregivers, they reported smoking even 100 and more cigarettes day.

Regarding the risk factors/protectors of cc in marginalized adolescents it was confirmed that $48.5 \%(n=432)$ presented pathogenic flora in the sample, represented by Trichomona vaginalis, fungi consistent with Candida $s p$ and suggestive of bacterial vaginosis. $15.3 \%$ of the patients presenting pathogenic flora declared not having initiated sexual life (table 1).

Table 1. Risk factors/protectors of cervical cancer

\begin{tabular}{|c|c|c|c|c|c|c|c|c|c|c|c|c|}
\hline \multirow{3}{*}{ Risk Factor/Protector } & \multicolumn{4}{|c|}{$\begin{array}{c}\text { Having Initiated Sexu- } \\
\text { al Activity }\end{array}$} & \multicolumn{4}{|c|}{$\begin{array}{l}\text { Having Not Initiated } \\
\text { Sexual Activity }\end{array}$} & \multirow{2}{*}{\multicolumn{2}{|c|}{$\begin{array}{c}\text { No Data } \\
\text { Yes }\end{array}$}} & \multirow{2}{*}{\multicolumn{2}{|c|}{$\begin{array}{c}\text { Total } \\
\text { No }\end{array}$}} \\
\hline & \multicolumn{2}{|c|}{ Yes } & \multicolumn{2}{|c|}{ No } & \multicolumn{2}{|c|}{ Yes } & \multicolumn{2}{|c|}{ No } & & & & \\
\hline & $\mathbf{n}$ & $\%$ & $\mathbf{n}$ & $\%$ & $\mathbf{n}$ & $\%$ & $\mathbf{n}$ & $\%$ & $\mathbf{n}$ & $\%$ & $\mathbf{n}$ & $\%$ \\
\hline Use of Barrier Methods & 44 & 4.9 & 703 & 79 & - & - & 126 & 14.1 & 18 & 2 & 891 & 100 \\
\hline Use of Hormonal Contraceptives & 86 & 9.7 & 644 & 72.3 & - & - & 126 & 14.1 & 35 & 3.9 & 891 & 100 \\
\hline History of Pregnancies & 121 & 13.6 & 573 & 64.3 & - & - & 126 & 14.1 & 71 & 7.9 & 891 & 100 \\
\hline Anomaly in Squamous Cells & 132 & 14.81 & 632 & 70.9 & 2 & 0.22 & 124 & 13.91 & 1 & 0.1 & 891 & 100 \\
\hline Pathogenic Bacterial Flora & 366 & 41.07 & 459 & 51.5 & 66 & 7.4 & 60 & 6.7 & - & - & 891 & 100 \\
\hline Tobacco Use & 567 & 63.6 & 167 & 18.74 & 92 & 10.3 & 34 & 3.81 & 31 & 3.4 & 891 & 100 \\
\hline More than One Sexual Partner & 594 & 66.7 & 157 & 17.6 & - & - & 126 & 14.1 & 14 & 1.6 & 891 & 100 \\
\hline $\begin{array}{l}\text { Early Initiation of Sexual Activity } \\
\text { (before Age 17) }\end{array}$ & 718 & 80.6 & 3 & 0.34 & - & - & 126 & 14.1 & 44 & 5 & 891 & 100 \\
\hline
\end{tabular}


The cytology results according to the Bethesda classification showed anomalies in the squamous cells of $15.04 \%$ of patients $(n=134)$. The frequency of HsiL was $0.2 \%$ corresponding to two patients (table 2).

Table 2. Anomalies of squamous cervical cytologies

\begin{tabular}{lcc}
\hline \multicolumn{1}{c}{ Type of Anomaly } & $\mathbf{n}$ & $\mathbf{\%}$ \\
\hline $\begin{array}{l}\text { Atypical squamous cells that do not allow an exclusion of high } \\
\text { grade intraepithelial lesion (ASC-H) }\end{array}$ & 1 & 0.11 \\
High grade squamous intraepithelial lesion (HSIL) & 2 & 0.22 \\
Atypical squamous cells of undetermined significance (ASC-US) & 64 & 7.19 \\
Low grade intraepithelial lesion (L-SIL) & 66 & 7.42 \\
No anomalies & 756 & 85.06 \\
Total & $\mathbf{8 8 9}$ & $\mathbf{1 0 0}$ \\
\hline
\end{tabular}

\section{Discussion}

$\mathrm{T}$

This study presents the results of Pap tests and risk factors of cc in females younger than 18 years who have lived in critical social conditions. Exposure to cc risk factors was considerably high. The initiation of sexual life turned out to be at an earlier age than in adolescents of the general population, reported between 15 and 16 years old by other authors (44-47). The number of sexual partners to whom they have been exposed throughout their lives is high, although the median turned out to be lower than the one reported by Saleh et al. in Great Britain, who found that $78 \%$ of adolescent females referred to colposcopy had had between 2 and 10 sexual partners (48).

The use of barrier methods was very low and coincides with the figure reported by Mendoza et al. in adolescents of Cali, Colombia, with just $5 \%$ (47). In other countries, slightly higher frequency rates have been found, such as, for instance, $11.8 \%$ in the study of Posso et al., and $14.7 \%$ in the research of Del Río et al. (44). It is noteworthy that the number of previous pregnancies is low (14\%) considering that $3 / 4$ of adolescent females did not use any contraception methods. Mendoza et al. reported previous pregnancy in 33\%, Saleh et al. found one previous pregnancy in $36 \%$ of the adolescent females $(47,48)$.

Regarding the anomalies in the Pap test, the frequency found in our study was the same as the one reported by Del Río et al. (44). By contrast, Mendoza et al. found only $7 \%$ of presence of anomalies in adolescents of the general population in the city of Cali, Colombia (47). This difference may suggest a high frequency of HPv infection in the group of teenagers in critical social conditions. 
For its part, frequency of high grade lesions was very low, as it is described in literature, and lies bellow what was reported by similar studies such as Del Río et al. with 3.2\%, Michala et al. with $2 \%$, and Mendoza et al. with $0.7 \%(44,45,47,49,50)$.

High exposure to risk factors can be explained as a consequence of the critical social conditions under which these adolescents have lived since very early ages, thus favoring the presence of multiple factors simultaneously. A similar study conducted in Malaysia in adolescents of a child protection center who have lived in the streets found that adolescent females have also been exposed to initiating sexual relations at an early age; sexual relations without protection, with multiple partners, and, furthermore, with males with a high probability of being carriers of sexually transmitted diseases (51).

However, it appears that the preoccupation over the change in the sexual behavior of the adolescents is not only limited to these particular groups, but it concerns also to the population in general (52). Therefore, it is sustained that the risk of cervical infections, inflammatory processes, and precancerous lesions not detected before in young females is growing (53).

The American and Canadian guidelines do not recommend cc screening in females younger than 21 years of age since the risk-benefit relation is not favorable and because the frequency of lesions requiring medical treatment is much too low (54). However, experts of the American Society of Colposcopy and Cervical Pathology (AScCP) in 2012 highlight that each country should adjust the guidelines according to the local conditions and suggest to consider health resources, training of healthcare workforce, adherence, and patients' expectations in each country (55). For its part, the Colombian Ministry of Health envisages within the frame of its guidelines the case of women younger than 25 years of age and orders: "It will perform an opportunity screening by cytology, based on the criterium and the assestment of previous history and risk factors performed by the physician or the nurse in order to justify its performance” (56).

The considerations outlined above suggest that teenage females with early and intensive exposure to cc risk factors could be included in screening programs following conservative and expectant protocols observing the evolution of lesions before initiating invasive procedures in the patient's uterine cervix.

On the other hand, gynecology consultations could be the opportunity for the adolescents to become aware of the implications of the exercise of sexuality, as well as to learn about risk factors, pregnancy prevention, prevention of sexually transmitted diseases (STDS), and the natural history of cc and how to prevent it. In this consultation, young females who have already initiated sexual relations should be assessed for the presence of sTDS, they should also receive the corresponding treatment if they are test-positive, and subsequently entering a screening program for cc, if advised by the physician.

Finally, the particular characteristics of the adolescent females included in this study compels the health sector to be aware of the existence of serious social issues such as sexual exploitation 
of children, trafficking in narcotics and crime networks that operate taking advantage of hostile family and school environments. This environment, attractive for some adolescents, favors abuse and the consequent exposure to risk factors for multiple pathologies. Multisectoral and multidisciplinary intervention is essential to approach this complex problem area given the present and future consequences it entails.

\section{Authors' Contribution}

$\mathrm{M}$ aría Inés Sarmiento Medina performed the conception and design of the study, developed the data analysis and interpretation, wrote the manuscript, and approved the final version to be published. Miryam Puerto de Amaya conceived the idea of the study, performed data acquisition and interpretation, conducted the critical review of the article's intellectual content, and carried out the final approval of the version to be published.

\section{Acknowledgements}

$\mathrm{W}$ express our thanks to David Sebastián Huertas Moreno and Yuleyma Katherynn Vargas Rojas, cytohystology students of the Fundación Universitaria de Ciencias de la Salud for their support in building the database.

\section{Funding}

Zundación Universitaria de Ciencias de la Salud.

\section{Conflict of Interests}

None declared. 


\section{References}

1. Bray F, Ferlay J, Soerjomataram I, Siegel R, Torre L, Jemel A, et al. Global Cancer Statistics 2018: gLoвосAN Estimates of Incidence and Mortality Worldwide for 36 Cancers in 185 Countries. CA Cancer J. Clin. 2018;68(6):394-424.

2. Global Cancer Observatory, World Health Organisation, International Agency for Research on Cancer. [internet]. Available from: https://gco.iarc.fr

3. Vaccarella S, Laversanne M, Ferlay J, Bray F. Cervical Cancer in Africa, Latin America and the Caribbean and Asia: Regional Inequalities and Changing Trends. Int J Cancer. 2017;141(10):1997-2001. Doi: https://doi.org/10.1002/ijc.30901

4. Organización Panamericana de la Salud. Cáncer cervicouterino [Internet] 2016. Available from: http://www.paho.org/hq/index.php?option=com_content\&view=article\&id=5420\%3A2011-cervical-cancer\&catid=1872\%3Acancer\&Itemid=3637=es .

5. Huertas J, Rivillas-García J, Ospina M. Progreso en el logro de los objetivos de desarrollo del milenio: la mortalidad por cáncer de cérvix desciende en Colombia. Rev Fac Nac Salud Pública;2015; 33(2): 286-90. Doi: 10.17533/udea.rfnsp.v33n2a15

6. Bernard V, Watson M, Castle P, Saraiya M. Cervical Carcinoma Rates Among Young Females in the United States. Obstet Gynecol. 2012;120(5):1117-1123.

7. Departamento Administrativo Nacional de Estadística Dane, Colombia. Estadísticas vitales, causas de defunción no fetal. Muertes por causa 20.9 “Tumores del Útero” - Causas agrupadas 6/67 OPS. Available from: http://microdatos.dane.gov.co/index.php/catalog/ MICRODATOS/about_collection/22/5

8. Walboomers J, Jacobs M, Manos M, Bosch F, Kummer J, Shah Ket al. Human Papillomavirus Is a Necessary Cause of Invasive Cervical Cancer Worldwide. J Pathol. 1999;189(1):12-9. Doi: 10.1002/(SICI)1096-9896(199909)189:1<12::AID-PATH431>3.0.CO;2-F

9. De San José S, Bosh F, Castellsagué X. Epidemiología de la infección por vpH y del cáncer de cuello de útero. SEMERGEn. 2007;33 Supl 2:9-21.

10. Castellsagué X, De San José S, Bosch F. Epidemiología de las infecciones por el virus del papiloma humano: nuevas opciones para la prevención del cáncer cervicouterino. In: Alonso P, Lascano E, Hernández M, eds. Cáncer cervicouterino: diagnóstico, prevención y control. $2^{\circ}$ ed. México: Editorial Médica Panamericana; 2005. p. 203-15.

11. Almonte M, Albero G, Molano M, Carcamo C, Garcìa P, Pérez G et al. Risk Factors for Human Papillomavirus Exposure and Co-Factors for Cervical Cancer in Latin America and the Caribbean. Vaccine 2008;26 (Suppl 11):L16-36. Doi: 10.1016/j.vaccine.2008.06.008

12. Castellsagué X, Bosch F, Muñoz N. Environmental Co-Factors in HPv Carcinogenesis. Virus Res. 2002;89(2):191-9.

13. Ribeiro A, Costa M, Alves R, Villa L, Saddi V, Carneiro M, et al. HPv Infection and Cervical Neoplasia: Associated Risk Factors. Infect Agent Cancer. 2015;10:16. Doi: 10.1186/s13027015-0011-3

14. Partridge J, Hughes J, Feng Q, Winer R, Weaver B, Xi L et al. Genital Human Papillomavirus Infection in Men: Incidence and Risk Factors in a Cohort of University Students. J Infect Dis. 2007;196(8):1128-36. Doi: 10.1086/521192 
15. Barrasso R, De Brux J, Croissant O, Orth G. High Prevalence of Papillomavirus-Associated Penile Intraepithelial Neoplasia in Sexual Partners of Women with Cervical Intraepithelial Neoplasia. N Engl J Med. 1987;317(15):916-23. Doi: 10.1056/NEJM198710083171502

16. Fulp W, Villa LL, Lazcano E, Papenfuss MR, Abrahamsen M, Salmeron et al. Incidence and Clearance of Genital Human Papillomavirus Infection in Men (HIM): A Cohort Study. Lancet 2011;377(9769):932-40. Doi: 10.1016/S0140-6736(10)62342-2

17. Louie KS, De Sanjose S, Díaz M, Castellsagué X, Herrero R, Meijer CJ. International Agency for Research on Cancer Multicenter Cervical Cancer Study Group. Early Age at First Sexual Intercourse and Early Pregnancy Are Risk Factors for Cervical Cancer in Developing Countries. Br J Cancer. 2009;100(7):1191-1197. Doi: 10.1038/sj.bjc.6604974

18. Appleby P, Beral V, Berrington de González A, Collin D, Franceschi S, Goodill A, et al. Carcinoma of the Cervix and Tobacco Smoking: Collaborative Reanalysis of Individual Data on 13,541 Women with Carcinoma of the Cervix and 23,017 Women without Carcinoma of the Cervix from 23 Epidemiological Studies. Int J Cancer. 2006;118(6):148195. Doi: 10.1002/ijc.21493.

19. Roura E, Castellsagué X, Pawlita M, Travier N, Waterboer T, Margall N, et al. Smoking as a Major Risk Factor for Cervical Cancer and Pre-Cancer: Results from the EPIC Cohort. Int. J. Cancer 2013;135: 453-466. Doi: 10.1002/ijc.28666

20. Vaccarella S, Herrero R, Snijders PJ, Dai M, Thomas JO, Hieu NT, et al. Smoking and Human Papillomavirus Infection: Pooled Analysis of the International Agency for Research on Cancer hpv Prevalence Surveys. Int J Epidemiol 2008;37:536-46. Doi: 10.1093/ije/dyn033

21. Poppe W, Ide P, Drijkoningen M, Lauweyns J, Van Assche F. Tobacco Smoking Impairs the Local Immunosurveillance in the Uterine Cervix. An Immunohistochemical Study. Gynecol Obstet Invest. 1995;39(1):34-8. Doi: 10.1159/000292372

22. Lee P, Thornton A, Hamling J. Epidemiological Evidence on Environmental Tobacco Smoke and Cancers Other than Lung or Breast. Regul Toxicol Pharmacol. 2016;80:13463. Doi: 10.1016/j.yrtph.2016.06.012

23. Eldridge R, Pawlita M, Wilson L, Castle P, Waterboer T, Gravitt P, et al. Smoking and Subsequent Human Papillomavirus Infection: A Mediation Analysis. Ann Epidemiol. 2017;27(11):724-30.e1. Doi: 10.1016/j.annepidem.2017.10.004

24. Boda D, Docea AO, Calina D, Ilie MA, Caruntu C, Zurac S et al. Human Papilloma Virus: Apprehending the Link with Carcinogenesis and Unveiling New Research Avenues (Review). Int J Oncology 2018;52(3):637-655. Doi: https://doi.org/10.3892/ijo.2018.4256

25. Silva J, Cerqueira F, Medeiros R. Chlamydia Trachomatis Infection: Implications for HPv Status and Cervical Cancer. Arch Gynecol Obstet. 2014;289(4):715-23. Doi: 10.1007/ s00404-013-3122-3

26. Zhu H, Shen Z, Luo H, Zhang W, Zhu X. Chlamydia Trachomati Infection-Associated Risk of Cervical Cancer. A Meta-Analysis. Medicine (Baltimore). 2016;95(13): e3077. Doi: 10.1097/MD.0000000000003077

27. Departamento de Salud y Servicios Humanos de los Estados Unidos - Centros para el Control y la Prevención de Enfermedades (CDC). Los condones y las ETs: Hoja informativa para el personal de salud pública. Available from: https://www.cdc.gov/condomeffectiveness/docs/Condoms_and_STDS_spanish.pdf 
28. Castellsagué X, Ault KA, Bosch X, Brown D, Cuzick J, Ferris DG, et al. Human Papillomavirus Detection in Cervical Neoplasia Attributed to 12 High-Risk Human Papillomavirus Genotypes by Region. Papillomavirus Res. 2016; 2: 61-69. Doi: 10.1016/j.pvr.2016.03.002

29. Grund JM, Bryant TS, Jackson I, Curran K, Bock N, Toledo C, et al. Association between Male Circumcision and Women's Biomedical Health Outcomes: A Systematic Review. Lancet Glob Health 2017; 5: e1113-22. Doi: 10.1016/S2214-109X(17)30369-8

30. Landy R, Pesola F, Castañón A, Sasieni P. Impact of Cervical Screening on Cervical Cancer Mortality: Estimation Using Stage-Specific Results from a Nested Case-Control Study. Br J Cancer. 2016;115(9):1140-1146. Doi: 10.1038/bjc.2016.290

31. Instituto Nacional de Cancerología-Ese, Sistema General de Seguridad Social en Salud Colombia. Guía de práctica clínica para la detección y manejo de lesiones precancerosas de cuello uterino - 2014. Guía Nr. 45 para profesionales de la salud. Available from: http://gpc.minsalud.gov.co/gpc_sites/Repositorio/Otros_conv/GPC_cuello_uterino_inv/ CCU_Guia_profesionales_julio_2016.pdf

32. Chatzistamatiou K, Moysiadis T, Moschaki V, Panteleris N, Agorastos T. Comparison of Cytology, HPV DNA testing and HPv 16/18 Genotyping Alone or Combined Targeting to the More Balanced Methodology for Cervical Cancer Screening. Gynecol Oncol. 2016;42(1):120-127. Doi: 10.1016/j.ygyno.2016.04.027

33. Canadian Partnership Against Cancer. New Cervical Cancer Screening Guidelines. Shifting from Overscreening Young Women to Minimize Harms [December 20, 2016]. Available from: https://www.partnershipagainstcancer.ca/news-events/news/article/ cervical-cancer-new-guidelines-shifting-overscreening-young-women/

34. Vesco K, Whitlock E, Eder M, Burda BU, Senger CA, Lutz K. Risk Factors and other Epidemiologic Considerations for Cervical Cancer Screening: A Narrative Review for the U.S. Preventive Services Task Force. Ann Intern Med. 2011;155(10):698-705. Doi: 10.7326/0003-4819-155-10-201111150-00377

35. Urrutia MT. Cáncer cervicouterino en Chile: análisis de un nuevo paradigma preventivo. Universidad de Chile, Temas de la agenda pública 2015;78. Available from: https:// politicaspublicas.uc.cl/wp-content/uploads/2015/06/N\%C2\%B0-78-C\%C3\%A1ncer-cervicouterino.-Nuevo-paradigama-preventivo..pdf

36. Asociación Española de Patología Cervical y Colposcopia. Guía de cribado del cáncer de cuello de útero en España 2014. Asociación Española de Patología Cervical y Colposcopia. IsBn: 978-84-608-3655-1. Available from: http://www.aepcc.org/wp-content/ uploads/2015/05/AEPCC_revista01.pdf

37. US Preventive Services Task Force: Curry S, Krist A, Owens D, Barry J, Caughey A, Davidson K. Screening for Cervical Cancer US Preventive Services Task Force Recommendation Statement. JAMA. 2018;320(7):674-686. Doi:10.1001/jama.2018.10897

38. European Comission against Cancer, International Agency for Research on Cancer. Cancer Screening in the European Unión 2017. Report on the Implementation of the Council Recommendation on Cancer Screening. p. 132. Available from: https://ec.europa. eu/health/sites/health/files/major_chronic_diseases/docs/2017_cancerscreening_2ndreportimplementation_en.pdf 
39. Vargas-Hernández VM. Estado cambiante del tamizaje en cáncer cérvico-uterino Rev Enf Trac Gen Inf 2018;11(1-4):4-6. Available from: http://www.comegic.org.mx/wp-content/ uploads/2018/05/Tracto-Genital-1-18.pdf

40. Lee M, Finlayson S, Gukova K, Hanley G, Miller D, Sadownik L. Outcomes of Conservative Management of High Grade Squamous Intraepithelial Lesions in Young Women. J Low Genit Tract Dis. 2018 Jul; 22(3): 212-218. Doi: 10.1097/LGT.0000000000000399

41. Moscicki AB. Cervical Cytology Screening in Teens. Curr Womens Health Rep. 2003;3:433437.

42. Zhang S, Thomas J, Thibodeaux J, Bhalodia A, Abreo F. Teenage Cervical Screening in a High Risk American Population. Cytojournal 2011;8:9. Doi: 10.4103/1742-6413.81773

43. Vash-Margita A, Flagler EN, Kobernik EK, Quint EH, Dalton VK. Trends in Cervical Cancer Screening in Adolescents. J Pediatr Adol Gynec 2017;30(2): 293-294. Doi: https://doi.org/10.1016/j.jpag.2017.03.056

44. Del Río-Ospina L, Soto-De León SC, Camargo M, Sánchez R, Mancilla CL, Patarroyo ME, et al. The Prevalence of High-Risk HPv Types and Factors Determining Infection in Female Colombian Adolescents. PLoS ONE. 2016;11(11):e0166502. Doi: https://doi.org/10.1371/ journal.pone.0166502

45. Michala L, Argyri E, Tsimplaki E, Tsitsika A, Bakoula C, Antsaklis A, et al. Human Papilloma Virus Infection in Sexually Active Adolescent Girls. Gynecol Oncol. 2012;126(2):207-10. Doi: 10.1016/j.ygyno.2012.04.042

46. Posso A, Rangel M, Marchán N, González M. Lesión intraepitelial cervical en adolescentes. Rev Obstet Ginecol Venez. 2014;74(3):193-202.

47. Mendoza L, Arias G, Pedroza P, Micolta P, Ramírez A, Cáceres C, et al. Actividad sexual en adolescencia temprana: problema de salud pública en una ciudad colombiana. Rev. Chil. Obstet. Ginecol. 2012;77(4):271-279. Doi: 10.4067/S0717-75262012000400006

48. Saleh MM, Seoud AA, Zaklama MS. Abnormal Cervical Smears in Adolescents: A TenYear Comparative Study of Demographic Criteria and Management. Clin Exp Obstet Gynecol 2007;34(3):139-42.

49. Jayasinghe Y, Moore E, Tabrizi S, Grover S, Garland S. Human Papillomavirus in Adolescents: Lessons Learned from Decades of Evaluation. J Paediatr Child Health. 2013;49(2):99-104. Doi: 10.1111/j.1440-1754.2011.02073.x

50. Moscicki AB. Cervical Cytology Screening in Teens. Curr Womens Health Rep. 2003;3:433-437.

51. Farid ND, Rus SC, Dahlui M, Al-Sadat N, Aziz NA. Predictors of Sexual Risk Behaviour among Adolescents from Welfare institutions in Malaysia: A Cross Sectional Study. BMc Public Health. 2014;14 Suppl 3:S9. Doi: 10.1186/1471-2458-14-S3-S9

52. Leung H, Lin L. Adolescent Sexual Risk Behavior in Hong Kong: Prevalence, Protective Factors, and Sex Education Programs. J Adolescent Health June 2019;64(6) Suppl: S52-S58 Doi: 10.1016/j.jadohealth.2018.12.007

53. Dallenbach G, Knebel M, Trunk M. Histopatología del cuello uterino. Atlas a color, $2^{\circ}$ ed. Journal Buenos Aires 2006 p VII y VIII, 209 p.

54. Vargas-Hernández VM, Acosta-Altamirano G, Vargas-Aguilar VM. New Guidelines in Regard to Cervical Cáncer Screening. Cir Cir 2014;82(4):453-459 
55. Massad LS, Einstein MH, Huh WK, Katki HA, Kinney WK, Schiffman M, et al. 2012 Updated Consensus Guidelines for the Management of Abnormal Cervical Cancer Screening Tests and Cancer Precursors. Available from: https://pdfs.semanticscholar.org/a827/571a281d0c8e10dda68991622b7b0f0d67a7.pdf

56. Ministerio de Salud y Protección Social. Colombia. Resolución No. 003280 de 2 agosto de 2018, p 168. Available from: http://legal.legis.com.co/document/Index?obra=legcol\& document=legcol_f63a1888c06e48a981ffa9117bc9129b 